\title{
CORPORATE VALUATION AND SOCIAL CAPITAL: A CROSS-COUNTRY ANALYSIS
}

Iñigo Fernández

Víctor M. González ${ }^{12}$

University of Oviedo

Abstract

This paper analyses the influence of social capital on corporate valuation for a sample of 55 countries over the period 1995-2012. The results suggest that social capital is an important determinant of corporate valuation. Interpersonal trust and civic cooperation enhance corporate valuation, even though other institutional and legal characteristics are considered. Furthermore, our results reveal that corporate valuation increases with the GDP annual growth rate, legal enforcement and the protection of shareholders' rights, but that it is negatively affected by corruption and protection of creditors' rights. We also obtain some evidence suggesting that civic cooperation has a greater influence over corporate valuation in poorer countries.

Keywords: corporate valuation, social capital, trust, civic cooperation

\footnotetext{
${ }^{1}$ Department of Business Administration. University of Oviedo. Avda. Del Cristo s/n. 33071 Oviedo. Spain, phone: + 34 985102826, fax: + 34 985103708, e-mail: vmendez@uniovi.es.

2 Financial support from the Spanish Ministry of Economy and Competitiveness and EDRF via Projects ECO201231772 and ECO2015-66184-R is gratefully acknowledged.
} 


\section{CORPORATE VALUATION AND SOCIAL CAPITAL: A CROSS-COUNTRY ANALYSIS}

\section{INTRODUCTION}

Several papers have shown that effective legal systems enhance corporate valuation, as investors are able to expect fair returns in these environments, revealing that country characteristics influence corporate valuation. La Porta et al. (2002) find evidence of a higher valuation of firms in countries with better protection of minority shareholders. This finding provides support for the importance of the expropriation of minority shareholders in many countries, as well as for the role of the rule of law in limiting such expropriation. Lee and $\mathrm{Ng}$ (2006) show that firms in more corrupt countries trade at significantly lower market multiples for a sample of companies from 44 countries, suggesting that corruption has significant economic consequences for shareholder value. Chua et al. (2007) analyse the key factors that drive cross-country differences in valuation for a sample of 49 countries over the period 19992004. Cross-country differences in corporate valuation are significantly explained by the growth options of countries, shareholder rights, the enforcement of insider trading laws and the degree of capital market openness.

Social capital has attracted a great deal of academic attention, especially since Putnam (1993) analysed the differences in the economic and institutional performance of northern and southern Italy, suggesting that civic engagement can lead to the enhancement of economic and institutional performance. Civic engagement gives rise to trust between the members of the community, even though they may disagree on key issues. Trust has been defined by La Porta et al. (1997) as the "propensity of people in a society to cooperate to produce socially efficient outcomes and to avoid inefficient non cooperative traps such as in the prisoner's dilemma". The economic benefits of social capital have been argued not only by Putnam (1993), but also by Goergen (2013), Goergen et al. (2013), Knack and Keefer (1997), La Porta et al. (1997), and Zak and Knack (2001). 
Within this context, the present paper focuses on the influence of social capital on corporate valuation. We extend the empirical literature on cross-country corporate valuation, considering the effect of the social capital of each country. Our results suggest that social capital is important as a determinant of corporate valuation even when institutional and legal determinants are considered.

The rest of the paper is organized as follows. Section 2 first reviews the literature on social capital to then focus on the development of the hypotheses. Section 3 discusses the methodology, variables and data sources employed, while Section 4 presents the empirical findings. Finally, Section 5 provides some concluding remarks.

\section{SOCIAL CAPITAL AND CORPORATE VALUE}

The study of social capital has attracted academic attention since Putnam (1993), in which social capital is used to explain differences in the economic and institutional performance of northern and southern Italy. Putnam (1993) shows that civic engagement is a determinant of the performance of local governments across Italian regions following constitutional reform in 1970, revealing that those Italian regions in which the public actively participate in civic activities (as a proxy of a high tendency to cooperate) are also the regions in which local governments show high levels of economic and institutional performance. The paper thus offers evidence that the regional governments in the more-trusting, more civic-minded northern and central regions of Italy provide public services more effectively than do those in the less-trusting, less civic-minded southern regions of Italy.

Knack and Keefer (1997) provide evidence of the importance of social capital on aggregate economic activity. Their paper tests the impact of interpersonal trust and civic norms (as measures of social capital) on both growth and investment rates for 29 different countries, revealing that the social capital variables exhibit a positive significant relationship with growth and investment. Knack and Keefer (1997) also report a significantly positive relationship between trust and output, capital and schooling. Furthermore, the impact of trust is higher in 
poorer countries where contracts are not reliably enforced by the legal system and where access to formal sources of credit is more limited due to the lesser development of the financial sector.

More recently, Zak and Knack (2001) empirically examine the predictions of a model in which heterogeneous agents transact and face a moral hazard problem for a sample of 44 countries. The model produces two main predictions: (1) higher trust increases investment and growth, and (2) homogeneous societies and egalitarian distributions of income enhance trust. Their empirical results reveal: (1) that investment is higher in countries where income inequalities are lower, where investment good prices are relatively low, and where trust is higher; and (2) a positive relationship between trust and growth. La Porta et al. (1997) show that the effects of trust on performance are statistically significant and quantitatively large. Trust raises judicial efficiency, bureaucratic quality and tax compliance, while corruption decreases with increasing trust. Moreover, trust has an effect on large firms' share of the economy, being found to increase the ratio of total sales of the 20 largest publicly traded firms in a country relative to its GNP. In line with Knack and Keefer (1997), Goergen (2013) show that trust has a positive effect on economic growth, an effect which is maintained after considering the influence of employment protection regulation and investor rights. Trust explains differences in economic growth among countries, while also explaining choices in terms of the institutional setting and investor and employment rights.

The previous literature shows that there is widespread consensus that economic activities that require some participants to rely on the future actions of others are accomplished at a lower cost in more-trusting and civic-minded environments. This evidence is consistent with the view of Arrow (1972), suggesting that much of the economic backwardness in the world is due to the lack of mutual confidence. Economic activities in which social capital is relevant include the provision of services or goods in exchange for future payment, contracts to accomplish tasks that are difficult to monitor, and investment decisions that rely on assurances by governments. 
The benefits of higher-trust societies include less expenses associated with protecting individuals from being exploited in economic transactions, less covenants in written contracts to specify every potential contingency, less litigation procedures, less resources for bribes, and less time devoted to monitoring partners, employees, suppliers, borrowers, and/or managers. In general, individuals in more-trusting and civic-minded countries are less dependent on formal institutions to enforce agreements and spend less to protect themselves from being exploited in economic transactions because interpersonal trust and civic norms reduce the cost of transactions and foster greater output. Due to the fact that the cost of transactions decreases with increasing trust, high trust countries will produce more output than low trust countries. Furthermore, more-trusting and civic-minded societies have a stronger incentive to innovate, accumulate physical capital, and obtain returns on the accumulation of human capital. Trust and civic-mindedness not only have these direct effects on economic activity, but may also improve economic output indirectly through political decisions (Putnam, 1993; La Porta et al., 1997). Within this context, we expect a positive influence of interpersonal trust and civic norms on corporate valuation. Hence, the main hypothesis tested in this paper is the following:

H1. More-trusting and civic-minded environments will have a positive relationship with corporate valuation.

Knack and Keefer (1997) show that the influence of trust on growth is higher in poorer countries, where contracts are not reliably enforced by the legal system and where access to formal sources of credit is more limited due to an underdeveloped financial sector. From this point of view, we would expect the influence of social capital to be higher in less economically developed countries. However, the effect of social capital on corporate valuation may increase with the economic development of the country, given that the number of transactions increases in developed countries. Consequently, the relevance of trust and civic norms should be higher in richer countries (Putnam, 1993). As both types of relationship between social 
capital and economic development are theoretically possible, we make no a priori forecast as to whether the effect of social capital is higher or lower according to the level of economic development, treating it as an empirical issue.

\section{DATABASES, METHODOLOGY AND VARIABLES}

The influence of social capital in explaining cross-country differences in corporate valuation is analysed for a sample of firms in 55 countries obtained from Compustat for the period 19962011 Our measure of valuation is Tobin's q (QTOBIN), defined as the ratio between the book value of assets minus the book value of common equity plus the market value of common equity and the book value of assets (Claessens et al., 2002; Durnev and Kim, 2005; La Porta et al., 2002). We compute Tobin's q for each firm for each year of the sample period. The median value for each year and country is consequently calculated ${ }^{3}$. Our empirical model is the following:

$$
\begin{aligned}
& \text { QTOBIN }_{k t}=a_{0}+a_{1} \text { GROWTH } \\
& a_{4}+a_{2} \text { SOCIAL_CAPITAL } L_{k t}+a_{3} \text { LEGAL }_{k t}+ \\
& a_{4} \text { CORUPT } \\
& k t \\
& +a_{5} C_{-} \text {RIGHTS }_{k t}+a_{6} S_{-} \text {RIGHTS }_{k}+\sum_{k t} \lambda_{k t}+\varepsilon_{k t}
\end{aligned}
$$

The estimations are carried out using ordinary least squares with year- and country-fixed effect $\left(\sum_{k t} \lambda_{k t}\right)$. This specific effect aims to control for most of the shocks affecting corporate valuation. This approach has the advantage of being less likely to suffer from omitted variable bias or model specification than traditional regressions (Dell'Ariccia et al., 2008). We estimate all our models with robust standard error and, in line with Petersen (2009), cluster the error term by country.

\footnotetext{
${ }^{3}$ A minimum number of 5 firms for year and country is required for a country to be included in the sample. The mean percentage of the market capitalization for the 55 countries in our sample compared with the market capitalization of the countries obtained from World Bank Cross Country Data is $69.87 \%$. Furthermore, only 8 countries in our sample have a percentage below $35 \%$ of the market capitalization of the country. These countries are Bulgaria, Egypt, Croatia, India, Jordan, Romania, Venezuela and Zimbabwe. When these countries are excluded from the estimations, the results are maintained.
} 
We test the impact of social capital (SOCIAL_CAPITAL) on corporate valuation using interpersonal trust (TRUST) and civic norms (CIVIC) as proxies of social capital. Interpersonal trust and civic norms are obtained from the World Values Surveys (WVS) and European Values Surveys (EVS), which are conducted in different countries in several "waves". The measure of trust we consider is the percentage of respondents in each country agreeing that "most people can be trusted"; hence, trust varies between 100 per cent (maximum value of interpersonal trust) and 0 per cent (minimum value of interpersonal trust) ${ }^{4}$.

An alternative measure of social capital that proxies the strength of civic cooperation norms is obtained from responses to questions about whether each of the following behaviours "can always be justified, can never be justified, or something in between": (1) Justifiable: Claiming government benefits which you are not entitled to; (2) Justifiable: Avoiding a fare on public transport; (3) Justifiable: Cheating on taxes if you have the chance; and (4) Justifiable: Someone accepting a bribe in the course of their duties. The value of each question varies between 1 (can never be justified) and 10 (can always be justified). We create an index that is the sum of the values of the four questions ${ }^{5}$. Thus, the CIVIC variable ranges between 4 (maximum value of civic cooperation) and 40 (minimum value of civic cooperation), constituting an inverse measure of civic cooperation in the country ${ }^{6}$.

Trust data from World Values Surveys (WVS) and European Values Surveys (EVS) has previously been used by Goergen (2013), Goergen et al. (2013), Knack and Keefer (1997), La Porta et al. (1997), and Zak and Knack (2001). Although, these surveys may have a wide range of potential problems (Inglehart, 1994), they produce values that are consistent with information from other sources. This is the case of a social experiment conducted by Reader's Digest ${ }^{7}$. The

\footnotetext{
${ }^{4}$ To compute this percentage of respondents, the "don't know" responses were previously removed.

${ }^{5}$ Knack and Keefer (1997) use a similar measure of norms of civic cooperation, in which they consider five instead of four components, as one of the components was not included in the latest surveys.

${ }^{6}$ As there is no data for TRUST and CIVIC for each year, the prior values of these variables are used when they are not available for any given year.

${ }^{7}$ A description of this social experiment can be followed at www.rd.com/slideshows/most-honest-citieslost-wallet-test/\#slideshow.
} 
magazine wanted to know how honest world cities are, so it dropped 192 wallets in 16 cities that is 12 wallets in each city- to see how many would be returned. Each wallet contained $\$ 50$ equivalent of local currency, as well as a name, phone number, family photo, coupons, and business cards. The number of wallets returned with their content was recorded for each city. The percentage of wallets returned in each country closely tracks the WVS/EVS measures, as it is correlated with TRUST at 0.67 (Knack and Keefer, 1997). Furthermore, most country values are consistent with popular impressions and anecdotal evidence, as the highest values of trust are reported for the Nordic countries. In the experiment conducted by Reader's Digest, the least honest city was Lisbon, where only 1 out of the 12 wallets was returned (by a nonresident visiting the city). The median value of TRUST for Portugal in our sample is 15.27 , which is far from the values of Nordic countries (Norway 69.17, Denmark 67.24, Sweden 65.39, and Finland 53.18).

To reduce endogeneity problems, we measure corporate valuation subsequent to the measurement of interpersonal trust and civic norms ${ }^{8}$. However, as social capital may not be totally exogenous, we resolve this question of potential endogeneity using instrumental variables estimation. We consider several variables as instruments of TRUST and CIVIC. The instruments for TRUST and CIVIC include the percentage of the population belonging to a hierarchical religion (Catholic, Eastern Orthodox, or Muslim), an index of ethnolinguistic diversity, the logarithm of GDP per capita, and the number of lawyers per population in millions (Knack and Keefer, 1997; Goergen, 2013; Goergen et al., 2013; La Porta et al., 1997; and Zak and Knack, 2001). Year and country fixed effects are also considered for both variables. We subsequently perform a Durbin-Wu-Hausman (DWH) test of overidentifying restrictions for each of the regressions. This test verifies the null hypothesis that the introduction of instrumental variables has no influence on the coefficients of the estimations. We accordingly perform a DWH F test for each of the estimations in our paper, the results of

\footnotetext{
${ }^{8}$ Furthermore, interpersonal trust may be assumed as exogenous, as it does not vary substantially across time (La Porta et al., 1997).
} 
which are reported in the bottom rows of each table. When the $p$ value of the $F$ test falls below 10 percent, the null hypothesis is rejected and the instrumental variables estimations are reported. Otherwise, the estimations with the observed values of TRUST and CIVIC variables are provided.

In line with previous research analysing corporate valuation, we consider growth opportunities, shareholders' rights, legal enforcement and corruption as determinants of the differences in corporate valuation (La Porta et al., 2002; Lee and Ng, 2006; Chua et al., 2007). Furthermore, we also consider the influence of the protection of creditors' rights on corporate valuation. We use the GDP growth rate to measure the growth opportunities in a country (GROWTH). GDP growth rate data are from the World Bank and are calculated as the annual percentage growth rate of GDP at market prices based on constant local currency.

In order to measure legal enforcement (LEGAL_ENFORC) and corruption (CORRUPTION), we use data from Worldwide Governance and the Heritage Foundation, respectively. As a measure of legal enforcement, we use the Worldwide Governance rule of law indicator, which captures perceptions of the extent to which agents have confidence in and abide by the rules of society and, in particular, the quality of contract enforcement, property rights, the police, and the courts, as well as the likelihood of crime and violence. This indicator ranges between 2.5 and -2.5 , with high values indicating stronger legal enforcement. As a proxy for corruption, we consider the Heritage Foundation's Freedom from Corruption Index, which measures the reduction in economic freedom caused by introducing insecurity and uncertainty in economic relationships. This index is based on a 100-point scale in which a score of 100 indicates very little corruption and a score of 0 indicates a very corrupt government ${ }^{9}$.

\footnotetext{
${ }^{9}$ This index relies on the following sources for information on informal market activities, in the following order of priority: Transparency International, Corruption Perceptions Index, 2011; U.S. Department of Commerce, Country Commercial Guide, 2009-2012; Economist Intelligence Unit, Country Commerce, 2009-2012; Office of the U.S. Trade Representative, 2012 National Trade Estimate Report on Foreign Trade Barriers; and official government publications of each country.
} 
Finally, our study also includes the explanatory variables: protection of creditors' rights and shareholders' rights. Data on creditors' rights (CREDITOR_RIGHTS) are from Djankov et al. (2007) and analyse some rights of secured lenders which are defined in the laws and regulations of different countries. This variable measures four powers of secured lenders in bankruptcy: (1) whether there are restrictions, such as creditor consent, when a debtor files for reorganization; (2) whether secured creditors are able to seize their collateral after the petition for reorganization is approved, i.e. whether there is no automatic stay or asset freeze imposed by the court; (3) whether secured creditors are paid first out of the proceeds of liquidating a bankrupt firm; and (4) whether an administrator, and not management, is responsible for running the business during the reorganization. A value of one is added to the index when a country's laws and regulations provide each one of these powers to secured lenders. It thus ranges between 0 and 4, with higher values indicating stronger creditors' rights or stronger protection against borrower expropriation. To measure shareholder rights, we use the anti-self-dealing index (SHAREHOLDER_RIGHTS) provided by Djankov et al. (2008). This index focuses on private enforcement mechanisms, such as disclosure, approval, and litigation, governing a specific self-dealing transaction and varies between 1 (maximum shareholder protection) and 0 (minimum shareholder protection).

Table 1 shows the characteristics of the sample. Panel A shows the descriptive statistics for the whole sample, including the mean, median, standard deviation, and minimum and maximum values. The average value of the dependent variable (QTOBIN) is 1.11. The average value of TRUST is 30.18, whereas that of CIVIC is 8.92. Panel B presents the mean values of the dependent and independent variables by country. The number of firms and the number of observations in each country are also provided. The third column in Table 1 presents the mean QTOBIN for each country. As can be seen, corporate valuation varies greatly across countries. For example, China has the highest QTOBIN (1.56) among all our sample countries, followed by the United States (1.45) and Australia (1.40). These values contrast with Latvia (0.62) and 
Venezuela (0.71), which have the lowest levels of corporate valuation. Column 5 shows the

values of TRUST, which varies substantially across countries. Norway has the highest trust level

(69.17), followed by Denmark (67.24) and Sweden (65.39). In contrast, Turkey (5.17), Brazil

(5.60) and Peru (7.39) have the lowest trust levels in our sample. Column 6 in Panel B presents

the mean value of civic norms for each country. As can be seen, Pakistan has the lowest level

(5.11), followed by Turkey (5.74) and Zimbabwe (6.01). In contrast, countries such as Malaysia

(14.50), the Philippines (13.60) and Thailand (13.02) present the highest values of civic norms.

Table 1. Descriptive statistics

The table reports the descriptive statistics of the dependent and independent variables. The data are from 1996 to 2011 for the 55 countries shown in the table. Our measure of corporate valuation is Tobin's q (QTOBIN), defined as the ratio between the book value of assets minus the book value of common equity plus the market value of common equity and the book value of assets. TRUST is the percentage of respondents agreeing that "most people can be trusted", obtained from the World Values Surveys (WVS) and European Values Surveys (EVS). CIVIC is an index that proxies the strength of civic cooperation norms and is likewise obtained from WVS and EVS. LEGAL_ENFORC is the Worldwide Governance rule of law indicator. CORRUPTION is the corruption index obtained from the Heritage Foundation. CREDITOR_RIGHTS measures the protection of creditors' rights. SHAREHOLDER_RIGHTS measures the protection of shareholders' rights. GROWTH is the GDP annual growth rate. LN_GDP is the natural logarithm of GDP per capita, GDP per capita being the gross domestic product in constant local currency divided by the midyear population.

\begin{tabular}{|c|c|c|c|c|c|c|c|c|c|c|c|}
\hline \multicolumn{12}{|c|}{ Panel A. Descriptive statistics } \\
\hline & & \multicolumn{3}{|c|}{ \# observations } & \multicolumn{2}{|c|}{ Mean } & Std. Dev. & Median & $\operatorname{Min}$ & \multicolumn{2}{|c|}{ Max } \\
\hline \multicolumn{2}{|c|}{ QTOBIN } & \multirow{2}{*}{\multicolumn{3}{|c|}{756}} & \multicolumn{2}{|c|}{1.11} & 0.29 & 1.07 & 0.28 & \multirow{2}{*}{\multicolumn{2}{|c|}{$\begin{array}{c}3.65 \\
76.04\end{array}$}} \\
\hline \multicolumn{2}{|c|}{ TRUST } & \multirow{2}{*}{\multicolumn{3}{|c|}{$\begin{array}{l}756 \\
705\end{array}$}} & \multicolumn{2}{|c|}{30.18} & 16.33 & 28.85 & 2.80 & & \\
\hline \multicolumn{2}{|c|}{ CIVIC } & & & & 8.9 & & 1.98 & 8.55 & 5.11 & 14.5 & \\
\hline LEGAL_EN & & & 756 & & $0.7-7$ r & & 0.95 & 0.85 & -1.76 & 2.00 & \\
\hline CORRUPT & & & 756 & & 57. & & 24.15 & 52.00 & 7.00 & 99.0 & \\
\hline CREDITOR_ & GHTS & & 756 & & 1.5 & & 1.11 & 2.00 & 0.00 & 4.00 & \\
\hline SHAREHOLDEF & RIGHTS & & 756 & & 0.4 & & 0.22 & 0.44 & 0.09 & $1.0 \mathrm{c}$ & \\
\hline Panel B. Descr & ptive stc & tistics by coun & & & & & & & & & \\
\hline Country & \# firms & \# observations & QTOBIN & TRUST & CIVIC & LEGAL_ENFORC & CORRUPTION & CREDITOR_RIGHTS & SHAREHOLDER_RIGHTS & GROWTH & LN_GDP \\
\hline Argentina & 71 & 798 & 0.92 & 16.51 & 8.28 & -0.37 & 33.64 & 1.00 & 0.34 & 3.05 & 9.02 \\
\hline Australia & 1,733 & 14,557 & 1.40 & 43.60 & 7.44 & 1.74 & 85.75 & 3.00 & 0.76 & 3.36 & 10.73 \\
\hline Austria & 89 & 1,015 & 1.05 & 34.58 & 8.62 & 1.85 & 79.69 & 3.00 & 0.21 & 2.12 & 10.66 \\
\hline Belgium & 131 & 1,480 & 1.12 & 31.38 & 10.37 & 1.29 & 68.62 & 2.00 & 0.54 & 1.89 & 10.62 \\
\hline Brazil & 322 & 2308 & 0.99 & 5.60 & 12.87 & -0.31 & 36.12 & 1.00 & 0.27 & 3.07 & 9.13 \\
\hline Bulgaria & 21 & 69 & 1.15 & 21.97 & 7.78 & -0.12 & 39.33 & 2.00 & 0.65 & 2.62 & 8.76 \\
\hline Canada & 718 & 7,779 & 1.32 & 42.25 & 7.61 & 1.72 & 88.75 & 1.00 & 0.64 & 2.63 & 10.69 \\
\hline Chile & 156 & 1,827 & 1.09 & 18.06 & 10.96 & 1.22 & 69.94 & 2.00 & 0.63 & 4.12 & 9.27 \\
\hline China & 2,378 & 14,797 & 1.56 & 52.98 & 7.45 & -0.42 & 32.19 & 2.00 & 0.76 & 9.83 & 7.72 \\
\hline Colombia & 38 & 299 & 0.93 & 12.40 & 9.52 & -0.67 & 32.31 & 0.00 & 0.57 & 3.32 & 8.56 \\
\hline Croatia & 25 & 150 & 0.93 & 20.28 & 9.58 & 0.01 & 39.00 & 3.00 & 0.25 & 2.21 & 9.42 \\
\hline Czech Rep & 12 & 113 & 1.01 & 26.68 & 9.90 & 0.83 & 46.50 & 3.00 & 0.33 & 2.85 & 9.70 \\
\hline Denmark & 170 & 1,812 & 1.05 & 67.24 & 6.31 & 1.89 & 83.94 & 3.00 & 0.46 & 1.36 & 10.93 \\
\hline Egypt & 41 & 265 & 1.21 & 27.41 & 6.54 & -0.07 & 31.38 & 2.00 & 0.20 & 4.76 & 7.69 \\
\hline Finland & 124 & 1,584 & 1.22 & 53.18 & 8.24 & 1.94 & 89.12 & 1.00 & 0.46 & 2.80 & 10.63 \\
\hline France & 645 & 7,180 & 1.16 & 20.44 & 10.96 & 1.41 & 70.44 & 0.00 & 0.38 & 1.66 & 10.56 \\
\hline Germany & 783 & 7,813 & 1.19 & 35.22 & 8.69 & 1.63 & 79.75 & 3.00 & 0.28 & 1.40 & 10.56 \\
\hline Greece & 218 & 1,929 & 1.24 & 22.99 & 11.60 & 0.76 & 45.31 & 1.00 & 0.22 & 1.64 & 10.17 \\
\hline Hong Kong & 432 & 4,043 & 0.97 & 41.05 & 8.55 & 1.53 & 81.71 & 4.00 & 0.96 & 4.60 & 10.30 \\
\hline Hungary & 17 & 173 & 1.15 & 25.59 & 10.56 & 0.84 & 50.06 & 1.00 & 0.18 & 2.29 & 9.34 \\
\hline India & 1,959 & 11,399 & 1.06 & 32.66 & 9.50 & 0.14 & 28.31 & 2.00 & 0.58 & 7.03 & 6.81 \\
\hline Indonesia & 359 & 3,774 & 1.05 & 46.73 & 7.37 & -0.74 & 21.62 & 2.00 & 0.65 & 4.96 & 7.81 \\
\hline Ireland & 60 & 696 & 1.36 & 37.78 & 8.86 & 1.61 & 75.43 & 1.00 & 0.79 & 4.55 & 10.67 \\
\hline Israel & 249 & 1,786 & 1.10 & 23.45 & 0.00 & 0.96 & 72.33 & 3.00 & 0.73 & 3.03 & 10.17 \\
\hline Italy & 260 & 2,878 & 1.08 & 31.62 & 7.69 & 0.62 & 49.56 & 2.00 & 0.42 & 0.87 & 10.49 \\
\hline Japan & 3,545 & 47,715 & 0.97 & 41.13 & 6.65 & 1.29 & 70.68 & 2.81 & 0.50 & 0.71 & 10.62 \\
\hline Jordan & 175 & 887 & 1.14 & 29.62 & 6.49 & 0.34 & 49.00 & 1.00 & 0.16 & 5.65 & 8.16 \\
\hline Korea Rep & 1,582 & 15,894 & 0.90 & 29.41 & 8.67 & 0.87 & 47.75 & 3.00 & 0.47 & 4.25 & 9.72 \\
\hline Latvia & 23 & 154 & 0.62 & 20.06 & 11.60 & 0.51 & 65.57 & 3.00 & 0.32 & 4.46 & 9.12 \\
\hline Malaysia & 911 & 10,058 & 0.87 & 8.80 & 14.50 & 0.51 & 50.00 & 3.00 & 0.95 & 4.68 & 9.04 \\
\hline Mexico & 106 & 1,169 & 1.07 & 21.42 & 12.67 & -0.54 & 34.94 & 0.00 & 0.17 & 3.10 & 9.04 \\
\hline Morocco & 54 & 285 & 1.30 & 17.52 & 6.80 & -0.08 & 37.77 & 1.00 & 0.56 & 4.32 & 7.75 \\
\hline Netherlands & 140 & 1,802 & 1.24 & 52.01 & 7.92 & 1.74 & 88.62 & 3.00 & 0.20 & 2.18 & 10.74 \\
\hline New Zealand & 113 & 1,063 & 1.22 & 49.97 & 7.45 & 1.84 & 94.19 & 4.00 & 0.95 & 2.27 & 10.34 \\
\hline Nigeria & 81 & 415 & 1.33 & 23.51 & 8.04 & -1.31 & 18.50 & 4.00 & 0.43 & 4.58 & - \\
\hline Norway & 198 & 1,751 & 1.16 & 69.17 & 7.88 & 1.90 & 87.56 & 2.00 & 0.42 & 2.19 & 11.33 \\
\hline Pakistan & 241 & 2,219 & 1.04 & 25.50 & 5.11 & -0.79 & 23.11 & 1.00 & 0.41 & 3.75 & 6.73 \\
\hline Peru & 81 & 741 & 0.98 & 7.39 & 9.94 & -0.66 & 36.50 & 0.00 & 0.45 & 4.78 & 8.22 \\
\hline Philippines & 209 & 2,416 & 0.89 & 7.58 & 13.60 & -0.27 & 29.77 & 1.00 & 0.22 & 4.02 & 7.37 \\
\hline Poland & 371 & 2,430 & 1.13 & 18.78 & 8.77 & 0.59 & 46.06 & 1.00 & 0.29 & 4.41 & 9.13 \\
\hline Portugal & 50 & 601 & 1.06 & 15.27 & 9.08 & 1.14 & 64.18 & 1.00 & 0.44 & 1.63 & 9.96 \\
\hline Romania & 39 & 148 & 1.02 & 16.01 & 8.38 & -0.11 & 32.73 & 2.60 & 0.44 & 2.31 & 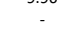 \\
\hline Russia & 164 & 834 & 0.96 & 25.75 & 11.27 & -0.91 & 24.87 & 1.75 & 0.44 & 3.90 & 8.95 \\
\hline Singapore & 643 & 6,167 & 1.04 & 14.70 & 9.02 & 1.44 & 90.83 & 3.00 & 1.00 & 5.34 & 10.39 \\
\hline Slovenia & 20 & 164 & 0.97 & 19.46 & 10.14 & 1.00 & 58.57 & 3.00 & 0.29 & 2.91 & 9.94 \\
\hline South Africa & 312 & 3,153 & 1.19 & 15.71 & 9.24 & 0.09 & 49.31 & 3.00 & 0.81 & 3.28 & 8.78 \\
\hline Spain & 139 & 1,695 & 1.18 & 26.78 & 8.30 & 1.23 & 62.81 & 2.50 & 0.37 & 2.60 & 10.27 \\
\hline Sweden & 373 & 3,317 & 1.30 & 65.39 & 9.15 & 1.85 & 92.31 & 1.00 & 0.33 & 2.72 & 10.74 \\
\hline Switzerland & 252 & 3,168 & 1.12 & 43.94 & 7.95 & 1.87 & 88.50 & 1.00 & 0.27 & 1.85 & 11.13 \\
\hline Thailand & 529 & 5,984 & 1.01 & 41.50 & 13.02 & -0.11 & 35.00 & 2.00 & 0.81 & 3.25 & 8.44 \\
\hline Turkey & 180 & 1,505 & 1.31 & 5.17 & 5.74 & 0.01 & 35.06 & 2.00 & 0.43 & 4.33 & 9.04 \\
\hline United Kingdom & 1,655 & 17,230 & 1.15 & 29.84 & 8.28 & 1.67 & 85.31 & 4.00 & 0.95 & 2.24 & 10.49 \\
\hline
\end{tabular}




\begin{tabular}{cccccccccccc} 
United States & 2,783 & 39,397 & 1.45 & 37.62 & 7.85 & 1.54 & 76.31 & 1.00 & 0.65 & 2.45 & 10.72 \\
Venezuela & 26 & 199 & 0.71 & 14.95 & 8.76 & -0.99 & 24.33 & 3.00 & 0.09 & 1.03 & 9.37 \\
Zimbabwe & 23 & 117 & 0.95 & 11.17 & 6.01 & -1.40 & 33.16 & 4.00 & 0.39 & -5.69 & 7.06 \\
\hline \hline
\end{tabular}

Table 2 shows the correlation matrix between the independent and dependent variables. High correlations do not exist among the variables used in the models, which could give rise to multicollinearity problems and hence inconsistent estimations in our models.

\section{Table 2. Correlations}

This table presents the correlation matrix. Our measure of corporate valuation is Tobin's q (QTOBIN), defined as the ratio between the book value of assets minus the book value of common equity plus the market value of common equity and the book value of assets. GROWTH is the GDP annual growth rate. TRUST is the percentage of respondents agreeing that "most people can be trusted", obtained from the World Values Surveys (WVS) and European Values Surveys (EVS). CIVIC is an index that proxies the strength of civic cooperation norms and is likewise obtained from WVS and EVS. LEGAL_ENFORC is the Worldwide Governance rule of law indicator. CORRUPTION is the corruption index obtained from the Heritage Foundation. CREDITOR_RIGHTS measures the protection of creditors' rights. SHAREHOLDER_RIGHTS measures the protection of shareholders' rights. LN_GDP is the natural logarithm of GDP per capita, GDP per capita being the gross domestic product in constant local currency divided by the midyear population.

\begin{tabular}{|c|c|c|c|c|c|c|c|c|}
\hline & QTOBIN & GROWTH & TRUST & CIVIC & LEGAL_ENFORC & CORRUPTION & CREDITOR_RIGHTS & SHAREHOLDER_RIGHTS \\
\hline QTOBIN & 1 & & & & & & & \\
\hline GROWTH & 0.2379 & 1 & & & & & & \\
\hline TRUST & 0.2423 & -0.0317 & 1 & & & & & \\
\hline CIVIC & -0.1746 & 0.0453 & -0.4190 & 1 & & & & \\
\hline LEGAL_ENFORC & 0.1943 & -0.1570 & 0.5747 & -0.1838 & 1 & & & \\
\hline CORRUPTION & 0.1816 & -0.1715 & 0.5589 & -0.1858 & 0.8987 & 1 & & \\
\hline CREDITOR_RIGHTS & -0.0634 & -0.0751 & 0.1791 & -0.2195 & 0.1942 & 0.2038 & 1 & \\
\hline SHAREHOLDER_RIGHTS & 0.1714 & 0.1250 & 0.1569 & -0.1294 & 0.1580 & 0.2203 & 0.2962 & 1 \\
\hline LN_GDP & 0.1490 & -0.2829 & 0.4600 & -0.0811 & 0.8396 & 0.7990 & 0.1973 & 0.0407 \\
\hline
\end{tabular}

As can be seen in Table 2, the dependent variable, QTOBIN, has a positive relationship with legal enforcement, corruption, the protection of shareholders' rights, and trust, but correlates negatively with the protection of creditor rights and civic norms. Likewise, interpersonal trust has a positive correlation with legal enforcement, corruption, the protection of shareholders' rights, and the protection of creditors' rights, but a negative correlation with civic norms. In contrast, CIVIC correlates negatively with legal enforcement, corruption, the protection of shareholders' rights and creditors' rights, and trust. As the correlation between legal enforcement and corruption is very high, these two variables are included alternatively in the estimations. The mean VIF factors are reported in the bottom row of Tables 3 and 4 . All mean VIF factors are below the benchmark of 10 , which is indicative of the absence of 
multicollinearity between the independent variables. The mean VIF factors increase in Table 4 due to the inclusion of interaction terms.

\section{Determinants of corporate valuation.}

The economic benefits of social capital have been argued by Putnam (1993), Knack and Keefer (1997), Zak and Knack (2001), Goergen (2013), and Goergen et al. (2013). However, these papers do not analyse their influence on corporate valuation. In this section, we therefore carry out an in-depth study of the relationship between social capital and country firm valuation. Table 3 examines the effect of social capital (interpersonal trust and civic norms) on corporate valuation across countries. We first study the effects of social capital on corporate valuation considering the two proxies: interpersonal trust (column 1) and civic norms (column 2). In column (1), the coefficient for TRUST is positive, as expected, and statistically significant at the $1 \%$ level, while the coefficient for the GDP annual growth rate is also positive and significant at the $1 \%$ level, in line with Chua et al. (2007). Similarly, column (2) shows that civic norms have a negative and significant coefficient ${ }^{10}$ at the $5 \%$ level, while the coefficient of GROWTH is positive and statistically significant, as in column (1). The positive coefficient of TRUST and the negative coefficient of CIVIC are consistent with more-trusting and civic-minded environments being positively influenced by social capital, as predicted in the first hypothesis.

The signs in the coefficients of TRUST and CIVIC are maintained when the characteristics of the legal and institutional environment are considered in the estimations in columns (3) through to (8). Similarly, the country's GDP annual growth rate presents a positive and significant coefficient in all the estimations. In columns (3) through to (8), we examine the effects of legal enforcement, corruption, and protection of shareholders' and creditors' rights and whether the inclusion of these variables has any effect on the influence of social capital on corporate valuation. Legal enforcement (LEGAL_ENFORC) has a positive influence on corporate valuation that is statistically significant in columns (3) and (7). The level of corruption in a country

10 The CIVIC index varies between 4 and 40, with higher values indicating low levels of civic cooperation. 
reduces corporate valuation, as low values of CORRUPTION indicate very corrupt countries.

Corporate valuation increases in countries with high levels of protection of shareholders' rights, revealing that shareholders pay more for firms in environments with better legal protection because the risk of being expropriated by a controlling shareholder is lower. The effect of legal enforcement, corruption, and protection of shareholders' rights is consistent with the results obtained by Chua et al. (2007). Finally, we examine the relationship between the protection of creditor's rights and firm value. This relationship is found to be negative and statistically significant in most of the estimations. When the rights of creditors are better protected, they will be more likely to force repayment and gain the control of firms (Aghion and Bolton, 1992). This will enable more entrepreneurs to finance their investments externally, while also reducing the value that shareholders are willing to pay for shares.

Table 3. Corporate valuation and social capital.

The dependent variable is QTOBIN, which is measured as the ratio between the book value of assets minus the book value of common equity plus the market value of common equity and the book value of assets. GROWTH is the GDP annual growth rate. TRUST is the percentage of respondents agreeing that "most people can be trusted", obtained from the World Values Surveys (WVS) and European Values Surveys (EVS). CIVIC is an index that proxies the strength of civic cooperation norms and is likewise obtained from WVS and EVS. LEGAL_ENFORC is the Worldwide Governance rule of law indicator. CORRUPTION is the corruption index obtained from the Heritage Foundation. CREDITOR_RIGHTS measures the protection of creditors' rights. SHAREHOLDER_RIGHTS measures the protection of shareholders' rights. Time and country effects are included in all the estimations, although we do not report their coefficients. Regressions are estimated using OLS with robust standard error and clustering the error term by country. The Durbin-Wu-Hausman statistic tests the null hypothesis that the introduction of instrumental variables has no influence on the coefficients of the estimations. We report instrumental variable estimations if the test is significant at the $10 \%$ level. T-statistics are in parentheses. ${ }^{* * *}, * *$, and $*$ represent significance at the $1 \%, 5 \%$, and $10 \%$ levels, respectively.

\begin{tabular}{|c|c|c|c|c|c|c|c|c|}
\hline & (1) & $(2)$ & (3) & (4) & (5) & (6) & (7) & (8) \\
\hline Intercept & $\begin{array}{l}0.9063^{* * *} \\
(18.23)\end{array}$ & $\begin{array}{l}1.2857^{* * *} \\
(13.43)\end{array}$ & $\begin{array}{l}0.9682^{* * *} \\
(20.46)\end{array}$ & $\begin{array}{l}0.8733^{* * *} \\
(13.41)\end{array}$ & $\begin{array}{l}0.9072^{* * *} \\
(15.46)\end{array}$ & $\begin{array}{l}0.8519^{* * *} \\
(13.50)\end{array}$ & $\begin{array}{l}1.2036^{* * *} \\
(11.53)\end{array}$ & $\begin{array}{l}1.1239^{* * *} \\
(9.01)\end{array}$ \\
\hline GROWTH & $\begin{array}{l}0.0196 * * * \\
(4.50)\end{array}$ & $\begin{array}{l}0.0219 * * * \\
(4.59)\end{array}$ & $\begin{array}{l}0.0199 * * * \\
(3.63)\end{array}$ & $\begin{array}{l}0.0201 * * * \\
(3.64)\end{array}$ & $\begin{array}{l}0.0191 * * * \\
(4.10)\end{array}$ & $\begin{array}{l}0.0191 * * * \\
(4.05)\end{array}$ & $\begin{array}{l}0.0224^{* * *} \\
(4.40)\end{array}$ & $\begin{array}{l}0.0225^{* * *} \\
(4.38)\end{array}$ \\
\hline TRUST & $\begin{array}{l}0.0045^{* * *} \\
(3.58)\end{array}$ & & & & $\begin{array}{l}0.0031^{* *} \\
(2.05)\end{array}$ & $\begin{array}{l}0.0033^{* *} \\
(2.25)\end{array}$ & & \\
\hline CIVIC & & $\begin{array}{l}-0.0271^{* *} \\
(-2.56)\end{array}$ & & & & & $\begin{array}{l}-0.0243^{* *} \\
(-2.43)\end{array}$ & $\begin{array}{l}-0.0249 * * \\
(-2.36)\end{array}$ \\
\hline LEGAL_ENFORC & & & $\begin{array}{l}0.0735^{* * *} \\
(3.25)\end{array}$ & & $\begin{array}{l}0.0436 \\
(1.61)\end{array}$ & & $\begin{array}{l}0.0678^{* * * *} \\
(3.25)\end{array}$ & \\
\hline CORRUPTION & & & & $\begin{array}{l}0.0027^{* * *} \\
(3.32)\end{array}$ & & $\begin{array}{l}0.0014 \\
(1.46)\end{array}$ & & $\begin{array}{l}0.0024^{* * *} \\
(3.35)\end{array}$ \\
\hline CREDITOR_RIGHTS & & & $\begin{array}{l}-0.0350^{*} \\
(-1.69)\end{array}$ & $\begin{array}{l}-0.0335 \\
(-1.62)\end{array}$ & $\begin{array}{l}-0.0378^{*} \\
(-1.93)\end{array}$ & $\begin{array}{l}-0.0371^{*} \\
(-1.90)\end{array}$ & $\begin{array}{l}-0.0450^{* *} \\
(-2.21)\end{array}$ & $\begin{array}{l}-0.0458^{* *} \\
(-2.22)\end{array}$ \\
\hline SHAREHOLDER_RIGHTS & & & $\begin{array}{l}0.1798^{*} \\
(1.80)\end{array}$ & $\begin{array}{l}0.1633 \\
(1.53)\end{array}$ & $\begin{array}{l}0.1698^{*} \\
(1.93)\end{array}$ & $\begin{array}{l}0.1611^{*} \\
(1.71)\end{array}$ & $\begin{array}{l}0.1732^{* *} \\
(1.99)\end{array}$ & $\begin{array}{l}0.1632^{*} \\
(1.77)\end{array}$ \\
\hline Time effects & Yes & Yes & Yes & Yes & Yes & Yes & Yes & Yes \\
\hline Country effects & Yes & Yes & Yes & Yes & Yes & Yes & Yes & Yes \\
\hline \# Observations & 756 & 705 & 756 & 756 & 756 & 756 & 705 & 705 \\
\hline \# countries & 55 & 54 & 55 & 55 & 55 & 55 & 54 & 54 \\
\hline F test & $9.39 * * *$ & $11.01 * * *$ & $6.89 * * *$ & $7.38 * * *$ & $6.61 * * *$ & $7.04 * * *$ & $11.53^{* * *}$ & $12.72 * * *$ \\
\hline R squared (\%) & 12.00 & 10.68 & 13.92 & 13.11 & 15.97 & 15.59 & 19.05 & 18.33 \\
\hline Durbin-Wu-Hausman test & 0.41 & 0.87 & - & - & 0.52 & 0.57 & 0.68 & 0.42 \\
\hline Mean VIF & 1.01 & 1.01 & 1.10 & 1.11 & 1.26 & 1.25 & 1.11 & 1.12 \\
\hline
\end{tabular}


The influence of the social capital proxies is economically significant. Using the coefficients in columns (5) and (7), a one-standard deviation increase in TRUST and CIVIC would respectively cause a variation in corporate valuation of 4.56 and -4.33 per cent. This respectively represents 17.46 and -16.59 per cent of the standard deviation of corporate valuation. These results confirm our first hypothesis even when other institutional and legal characteristics are considered.

Table 4 shows the results when we consider whether the effect of social capital on corporate valuation varies according to the level of economic development of the country. The evidence documented by Knack and Keefer (1997) shows that the influence of trust on growth is higher in less developed countries, where contracts are not reliably enforced by the legal system and where access to formal sources of credit is more limited due to an underdeveloped financial sector. However, Putnam (1993) posits that the relevance of social capital should be higher in richer countries, as it could reduce transaction costs and the number of transactions is higher in more economically developed countries.

In this context, we incorporate a new variable in our model related to the economic development of the country (LN_GDP). LN_GDP is the natural logarithm of GDP per capita, GDP per capita being the gross domestic product in constant local currency divided by the midyear population. In columns (1) and (2), TRUST measures the effect of this variable on corporate valuation in less developed countries, while the interaction term LN_GDP*TRUST measures the differential influence of TRUST in countries with higher GDP per capita.

On the one hand, TRUST and the interaction term LN_GDP*TRUST are positive and negative, respectively, in columns (1) and (2), although not statistically significant at conventional levels. The negative coefficient associated with the interaction term suggests that the effect of TRUST is higher in richer countries, although the differences are not statistically significant at standard levels. 
Table 4. Corporate valuation, social capital and economic development

The dependent variable is QTOBIN, which is measured as the ratio between the book value of assets minus the book value of common equity plus the market value of common equity and the book value of assets. GROWTH is the GDP annual growth rate. TRUST is the percentage of respondents agreeing that "most people can be trusted", obtained from the World Values Surveys (WVS) and European Values Surveys (EVS). CIVIC is an index that proxies the strength of civic cooperation norms and is likewise obtained from WVS and EVS. LN_GDP is the natural logarithm of GDP per capita, GDP per capita being the gross domestic product in constant local currency divided by the midyear population. LEGAL_ENFORC is the Worldwide Governance rule of law indicator. CORRUPTION is the corruption index obtained from the Heritage Foundation. CREDITOR_RIGHTS measures the protection of creditors' rights. SHAREHOLDER_RIGHTS measures the protection of shareholders' rights. Time and country effects are included in all the estimations, although we do not report their coefficients. Time and country effects are included in all the estimations, although we do not report their coefficients. Regressions are estimated using OLS with robust standard error and clustering the error term by country. The Durbin-Wu-Hausman statistic tests the null hypothesis that the introduction of instrumental variables has no influence on the coefficients of the estimations. We report instrumental variable estimations if the test is significant at the $10 \%$ level. T-statistics are in parentheses. ${ }^{* * *}, * *$, and $*$ represent significance at the $1 \%, 5 \%$, and $10 \%$ levels, respectively.

\begin{tabular}{|c|c|c|c|c|}
\hline & (1) & $(2)$ & (3) & (4) \\
\hline \multirow{2}{*}{ Intercept } & 0.6313 & 0.4252 & $1.8807^{* * *}$ & $1.7323 * * *$ \\
\hline & $(1.44)$ & $(1.12)$ & (3.10) & $(2.97)$ \\
\hline \multirow{2}{*}{ GROWTH } & $0.0179 * * *$ & $0.0183 * * *$ & $0.0229 * * *$ & $0.0237 * * *$ \\
\hline & (3.58) & (3.90) & (3.81) & (4.27) \\
\hline \multirow{2}{*}{ TRUST } & 0.0098 & 0.0116 & & \\
\hline & $(0.92)$ & $(1.13)$ & & \\
\hline CIVIC & & & $\begin{array}{l}-0.1360 * * \\
(-2.10)\end{array}$ & $\begin{array}{l}-0.1401^{* *} \\
(-2.02)\end{array}$ \\
\hline \multirow{2}{*}{ LN_GDP } & 0.0311 & 0.0480 & -0.0775 & -0.0653 \\
\hline & $(0.71)$ & $(1.21)$ & $(-1.13)$ & $(-0.97)$ \\
\hline \multirow{2}{*}{ LN_GDP*TRUST } & -0.0007 & -0.0009 & & \\
\hline & $(-0.71)$ & $(-0.88)$ & & \\
\hline LN_GDP*CIVIC & & & $\begin{array}{l}0.0125^{*} \\
(1.74)\end{array}$ & $\begin{array}{l}0.0128 \\
(1.67)\end{array}$ \\
\hline LEGAL_ENFORC & $\begin{array}{l}0.0515 \\
(1.34)\end{array}$ & & $\begin{array}{l}0.0566^{*} \\
(1.71)\end{array}$ & \\
\hline CORRUPTION & & $\begin{array}{l}0.0013 \\
(0.93)\end{array}$ & & $\begin{array}{l}0.0014 \\
(1.18)\end{array}$ \\
\hline CREDITOR_RIGHTS & $\begin{array}{l}-0.0517 * * * \\
(-2.75)\end{array}$ & $\begin{array}{l}-0.0507 * * * \\
(-2.71)\end{array}$ & $\begin{array}{l}-0.0553^{* * *} \\
(-2.93)\end{array}$ & $\begin{array}{l}-0.0553^{* * *} \\
(-2.93)\end{array}$ \\
\hline SHAREHOLDER_RIGHTS & $\begin{array}{l}0.1808^{* *} \\
(2.03)\end{array}$ & $\begin{array}{l}0.1736^{*} \\
(1.70)\end{array}$ & $\begin{array}{l}0.2095^{* *} \\
(2.31)\end{array}$ & $\begin{array}{l}0.2103^{* *} \\
(2.15)\end{array}$ \\
\hline Time effects & Yes & Yes & Yes & Yes \\
\hline Country effects & Yes & Yes & Yes & Yes \\
\hline \# Observations & 733 & 733 & 682 & 682 \\
\hline \# countries & 53 & 53 & 52 & 52 \\
\hline F test & $7.23 * * *$ & $6.53 * * *$ & $13.74 * * *$ & $14.45^{* * *}$ \\
\hline R squared (\%) & 17.96 & 17.63 & 22.38 & 21.96 \\
\hline Durbin-Wu-Hausman test & 0.43 & 0.45 & 0.69 & 0.71 \\
\hline Mean VIF & 25.58 & 26.56 & 24.14 & 6.24 \\
\hline
\end{tabular}

On the other hand, CIVIC has a negative influence on corporate valuation that is marginally significant different depending on the level of economic development of the countries. The interaction term LN_GDP*CIVIC has a positive and significant coefficient in column (3) and 
non-significant coefficient in column (4). These results show that corporate valuation increases with civic cooperation, with some differences among countries depending on their level of economic development, revealing that the positive relationship between civil norms and corporate valuation is predominant in poorer countries. This result is consistent with Knack and Keefer (1997).

The coefficients of the characteristics of the legal and institutional environment considered in the estimations are similar to those provided in Table 3. The GDP annual growth rate presents a positive and significant influence in all the estimations. Legal enforcement and protection of shareholders' rights promote corporate valuation, while protection of creditors' rights has a negative effect on corporate valuation. However, corruption is not significant in explaining corporate valuation when we consider the interaction effect between social capital and economic development.

\section{CONCLUSION}

This paper analyses the influence of social capital on corporate valuation for an international sample of firms belonging to 55 countries over the period 1996-2011. We show that crosscountry variations in corporate valuation are driven not only by legal and institutional characteristics, but also by the country's social capital. We find that firms in more-trusting and civic-minded countries have a higher valuation. Our contribution in this paper is that of empirically showing that the social capital variables interpersonal trust and civic cooperation play an important role in understanding differences in country firm valuation. This evidence is consistent with the literature analysing social capital, which highlights its positive effect on investment and growth. Furthermore, we obtain some evidence that the influence of civic norms explains corporate valuation to a greater extent in poorer countries. These results allow us to confirm the importance of social capital as a significant factor in understanding how firm country valuation is built. 
Furthermore, our results reveal that corporate valuation increases with the GDP annual growth rate, legal enforcement, and the protection of shareholders' rights, whereas it is negatively affected by corruption and the protection of creditors' rights.

\section{References}

Aghion, P. and Bolton, P., 1992. An Incomplete Contracts Approach to Financial Contracting. The Review of Economic Studies 59 (3), 473-494.

Arrow, K., 1972. Gifts and exchanges. Philosophy and Public Affairs I, 343-362.

Chua, C.T., Eun, C.S., and Lai, S., 2007. Corporate Valuation around the World: The Effects of Governance, Growth, and Openness. Journal of Banking and Finance 31, 35-56.

Claessens, S.; Djankov, S.; Fan, J.P.H., and Lang, L.H.P. 2002. Disentangling the Incentive and Entrenchment Effects of Large Shareholdings. The Journal of Finance 57 (6), 2741-2771.

Dell'Ariccia, G., Detragiache, E., and Rajan. R., 2008. The Real Effect of Banking Crises. Journal of Financial Intermediation 17, 89-112.

Djankov, S.; McLiesh, C., and Shleifer, A., 2007. Private credit in 129 countries. Journal of Financial Economics 84, 299-329.

Djankov, S., La Porta, R., Lopez-de-Silanes, F., Shleifer, A., and Vishny, R.W., 2008. The Law and Economics of Self-Dealing. Journal of Financial Economics 88 (3), 430-465.

Durnev, A. and Kim, E.H., 2005. To Steal or Not to Steal: Firm Attributes, Legal Environment, and Valuation. The Journal of Finance 60 (3), 1461-1493.

Goergen, M., 2013. Corporate stakeholders and trust. The Spanish Review of Financial Economics $11(2), 47-56$. 
Goergen, M., Chahine, S., Brewster, C., and Wood, G., 2013. Trust, Owner Rights, Employees and Firm Performance. Journal of Business Finance \& Accounting 40 (5-6), 589-619.

Gordon, R.G., 2005. Ethnologue: Languages of the World, $15^{\text {th }}$ edition. SIL International, Dallas.

Inglehart, R. 1994. Codebook for World Values Surveys. Ann Arbor, MI: Institute for Social Research.

Kaufmann, D., Kraay, A., and Mastruzzi, M., 2010. The Worldwide Governance Indicators: A Summary of Methodology, Data and Analytical Issues. World Bank Policy Research Working Paper No. 5430. http://papers.ssrn.com/sol3/papers.cfm?abstract_id=1682130.

Knack, S. and Keefer, P., 1997. Does Social Capital Have an Economic Payoff? A Cross-country Investigation. Quarterly Journal of Economics 112 (4), 1251-1288.

La Porta, R., Lopez-de-Silanes, F., Shleifer, A. and Vishny, R.W., 1997. Trust in Large Organizations. American Economic Review 87 (2), 333-338.

La Porta, R.; Lopez de Silanes, F.; Shleifer, A., and Vishny, R.W., 2002. Investor Protection and Corporate Valuation. The Journal of Finance 57 (3), 1147-1170.

Lee, C. and Ng, D., 2009. Corruption and International Valuation: Does Virtue Pay? The Journal of Investing 18 (4), 23-41.

Lieberson, S., 1981. Language diversity and language contact. Stanford University Press, Stanford.

Petersen, M, 2009. Estimating Standard Errors in Finance Panel Data Sets: Comparing Approaches. The Review of Financial Studies 22 (1), 435-480.

Putnam, R.D., 1993. Making Democracy Work. Civic Traditions in Modern Italy, Princeton: Princeton University Press. 
Zak, P.J. and Knack, S., 2001. Trust and Growth. Economic Journal 111, 295-321. 


\section{Appendix A. Variables}

The table shows the definition of variables used in the paper and their sources.

\begin{tabular}{ll}
\hline \hline Name & Definition \\
\hline & DEPENDENT VARIABLE \\
\hline QTOBIN & $\begin{array}{l}\text { The ratio between the book value of assets minus the book value of common equity plus the market } \\
\text { value of common equity and the book value of assets for each firm and year. The median value for } \\
\text { each year and country is calculated. }\end{array}$
\end{tabular}

SOCIAL CAPITAL VARIABLES

TRUST The percentage of respondents in each country agreeing that "most people can be trusted".

World Values Survey (WVS) and European Values Survey (EVS)

The strength of civic cooperation norms is obtained from responses to questions about whether each of the following behaviours "can always be justified, can never be justified or something in between": (1) claiming government benefits which you are not entitled to; (2) avoiding a fare on public transport; (3) cheating on taxes if you have the chance; and (4) someone accepting a bribe in the course of their duties.

World Values Survey (WVS) and European Values Survey (EVS)

CONTROL VARIABLES

GROWTH The annual percentage growth rate of GDP at market prices based on constant local currency.

World Bank (World Bank national accounts data, and OECD National Accounts data files).

$\begin{array}{ll}\text { This captures perceptions of the extent to which agents have confidence in and abide by the rules of } \\ \text { LEGAL_ENFORC } & \text { society and, in particular, the quality of contract enforcement, property rights, the police, and the }\end{array}$ courts, as well as the likelihood of crime and violence.

Worldwide Governance Indicators (Kaufman et al., 2010).

The index "Freedom from Corruption" measures the reduction in economic freedom caused by CORRUPTION introducing insecurity and uncertainty in economic relationships. The score for this component of Economic Freedom is derived primarily from Transparency International's Corruption Perceptions Index (CPI) for 2011, which measures the level of corruption in 183 countries.

This index measures four powers of secured lenders in bankruptcy: (1) whether there are restrictions, such as creditor consent, when a debtor files for reorganization; (2) whether secured creditors are able to seize their collateral after the petition for reorganization is approved, i.e. whether there is no automatic stay or asset freeze imposed by the court; (3) whether secured creditors are paid first out of the proceeds of liquidating a bankrupt firm; and (4) whether an administrator, and not management, is responsible for running the business during the reorganization. A value of one is added to the index when a country's laws and regulations provide each one of these powers to secured lenders; it thus varies between 0 (poor creditor rights) and 4 (strong creditor rights).

Heritage Foundation.

The anti-self-dealing index focuses on private enforcement mechanisms, such as disclosure, approva and litigation, governing a specific self-dealing transaction.

Djankov et al. (2008).

\section{INSTRUMENTAL VARIABLES}

RELIGION

The percentage of population belonging to a hierarchical religion (Catholic, Eastern Orthodox, or Muslim).

La Porta et al. (1997)

Council of Bars and Law Societies of Europe (CCBE), the American Bar Association, and various national and international

N_LAWYERS The number of lawyers per population in millions. organizations. Population in millions from World Development Indicators.

DIVERSITY

The probability that any two randomly chosen inhabitants of a country will have different mother tongues (Lieberson, 1981).

Gordon (2005).

World Bank (World Bank

The natural logarithm of GDP per capita. GDP per capita is gross domestic product in constant local currency divided by the midyear population. 